\title{
Treatment and Valorization of Leachates from Controlled Landfills by Composting the Fermentable Fraction of Household and Assimilated Waste
}

\author{
Hicham Charkaoui ${ }^{1}$, Mustapha Benbouya ${ }^{2}$, Khalid El Ass ${ }^{3}$, Said Kitane ${ }^{3}$, Abdelmejid Bahloul ${ }^{4, *}$, \\ Souad El Hajjaji ${ }^{1}$ and Azzeddine El Midaoui ${ }^{2}$ \\ ${ }^{1}$ Laboratory of Spectroscopy, Molecular Modeling, Materials, Nanomaterials, Water and Environment, Faculty of \\ Sciences Rabat, Mohamed V University, 4 Av Ibn Battouta, BP 1014 RP, Rabat, Morocco \\ ${ }^{2}$ Laboratory of Separation Processes, Faculty of Sciences Kenitra, Ibn Tofail University, Maamora District, B.P \\ 133-14000, Kenitra, Morocco \\ ${ }^{3}$ Laboratory of Environmental Metrology, National School of Mines of Rabat, Av Hadj Ahmed Cherkaoui, B.P \\ 753 Agdal, Rabat, Morocco \\ ${ }^{4}$ Laboratory of Biomolecules and Organic Synthesis, Faculty of Sciences Ben M'Sik, Hassan II University of \\ Casablanca, Av Driss El Harti, B.P 7955, Sidi Othmane Casablanca, Morocco
}

\begin{abstract}
Leachate generated by urban waste is one of the significant constraints of landfill management. Because of their pollutant load, it poses a threat to the environment and human health. It is, therefore, imperative to contribute to its elimination. This work consists in proposing a reliable and feasible solution based on an integrated research and development approach that respects the concept of 3R (reduction, recycling and reuse). The solution is to use leachate instead of water in the composting process of the organic fraction of household waste. A platform was built on the site of the Mohammedia landfill, located near the city of Rabat, the Moroccan capital, to conduct an experimental study on 30 tons of household and similar waste (HAW). The sorting operation allowed to separate the fermentable fraction of $58.26 \%$. Leachate stored on-site was used for composting. The results found that the composting process caused the consumption of about $8.1 \mathrm{~m}^{3}$ of leachate and the production of 5.85 tons of compost at $9 \%$ moisture.
\end{abstract}

Keywords: Landfill management; sorting operation, fermentable fraction; leachate elimination; composting process.

\section{Introduction}

The amount of solid waste generated in Morocco, as is the case in all developing countries, poses a severe threat to the environment and public health, given the fact that the current conditions of collection, transportation, landfilling or recycling of this waste are insufficient ${ }^{1}$.

It is well known that leachate from urban waste is one of the significant constraints for the management of landfills. In fact, because of their pollutant load, they represent a threat to the environment and human health ${ }^{2-4}$.

Water is the primary vector of landfill leachate evolution. Inputs to a storage center consist of direct rainfalls plus water supplied by the waste.

The chemical and biochemical compositions of leachate are not only very diverse but also variable in time and space. More than 200 families of organic

*Corresponding author: Abdelmejid Bahloul

Email address: bahloulwipo@gmail.com

DOI: http://dx.doi.org/10.13171/mjc91190810100ab compounds have been identified in numerous studies on the characterization of leachate in waste disposal centers ${ }^{5}$. Among them, cyclic or aromatic carbon compounds but also alcohols, ethers, ketones, acids, phenols, phthalates, furans and finally nitrogen compounds, sulfur and phosphorus ${ }^{6}$.

Of all these molecules, some, such as chloro- and dichlorobenzene, toluene, styrene, naphthalene and xylenes, are recognized as priority pollutants and pose a serious threat to the environment.

It should also be noted that the physicochemical quality of leachate depends on many factors such as the mode of operation of the repository (the management of the site, its topography, its geographical location and the degree of compaction of the waste). It also depends on the seasonal climatic variations (precipitation, humidity, 
evapotranspiration ...), but especially the nature of stored waste, and their stage of evolution (age) ${ }^{7-11}$.

Depending on the stage of the biological evolution of the waste, three types of leachate were distinguished (Table 1):

- Young leachate: characterized by a relatively biodegradable high organic load. These leachates can be loaded with metals (up to $2 \mathrm{~g} / \mathrm{L}$ ) because of their relatively low $\mathrm{pH}(<6.5)$.

- Intermediate leachate: As the waste stabilizes, the organic load decreases and volatile fatty acids (VFA) become scarce in favor of compounds of high molecular weight. The emergence of these compounds tends to decrease the biodegradability of the leachate. As a result, the $\mathrm{pH}$ is close to neutral, and the metal charge becomes negligible.

- Aged or stabilized leachate: characterized by a low organic load, composed mainly of humic substances (fulvic and humic acids). Also present are compounds of low molecular weight just as refractory to biodegradation.

Table1. Temporal evolution of chemical and physicochemical characteristics of leachate ${ }^{12,13}$.

\begin{tabular}{|l|c|c|c|}
\hline & leachate young & Intermediate leachate & Stabilized leachate \\
\hline Age (year) & $<5$ & $5-10$ & $>10$ \\
\hline $\mathrm{pH}$ & $<7$ & $=7$ & $>7$ \\
\hline $\mathrm{COD}\left(\mathrm{g} \mathrm{O}_{2} / \mathrm{L}\right)$ & $>20$ & $3-15$ & $<2$ \\
\hline $\mathrm{BOD}_{5} / \mathrm{COD}$ & $>0.3$ & $0.1-0.3$ & $<0.1$ \\
\hline & $\begin{array}{c}80 \% \text { Volatile Fatty } \\
\text { Acids (VFA) }\end{array}$ & $\begin{array}{c}5-30 \% \text { VFA + Humic and } \\
\text { Fulvic Acids }\end{array}$ & Humic and Fulvic Acids \\
\hline
\end{tabular}

Also, leachate flow control consists first of all in confining waste to prevent groundwater pollution, then collecting leachate, storing them and then treating them. Leachate can only be released into the natural environment after treatment and provided that its composition complies with the regulatory rejects values.

In Morocco, the amount of household and assimilated waste (HAW) currently stands at $8 \mathrm{Mt} / \mathrm{yr}{ }^{14}$ with a collection rate of around $90 \%$ by 2020 and to have only landfills controlled by the National Household
Waste Program (NHWP). The quantities of HAW and leachate produced at certain landfills in Morocco are given in Table 2.

Leachate produced in Moroccan landfills is characterized by very high $\mathrm{COD}, \mathrm{BOD}_{5}$, conductivity values ${ }^{14}$, and pathogens which means that these leachates must be cleaned up before any use/reuse or direct discharge into the natural environment.

In addition, leachates are rich in pathogens, which also requires hygienization before they are rejected ${ }^{15-17}$.

Table 2. Quantities of HAW and de leachate produced at different Moroccan public landfills ${ }^{7,8,18-20}$.

\begin{tabular}{|l|c|c|c|c|c|}
\hline City & $\begin{array}{c}\text { HAW } \\
\text { t/day }\end{array}$ & $\begin{array}{c}\text { HAW } \\
\text { t/year }\end{array}$ & $\begin{array}{c}\text { Leachate } \\
\mathrm{m}^{3} / \mathrm{day}\end{array}$ & $\begin{array}{c}\text { Leachate } \\
\mathrm{m}^{3} / \mathrm{year}\end{array}$ & $\begin{array}{c}\text { Leachate / } \\
\text { HAW } \\
\mathrm{m}^{3} / \mathrm{t}\end{array}$ \\
\hline Agadir & 360 & 131.400 & 150 & 54750 & 0.42 \\
\hline Tangier & 572 & 208.780 & 262 & 95630 & 0.46 \\
\hline Fez & 900 & 328.500 & 360 & 131400 & 0.40 \\
\hline El Jadida & 425 & 155.125 & 156 & 56940 & 0.37 \\
\hline Rabat & 1792 & 654080 & 480 & 175200 & 0.27 \\
\hline Casablanca & 3800 & 1387000 & 1400 & 511000 & 0.37 \\
\hline Oujda & 418.8 & 152862 & 100 & 36500 & 0.24 \\
\hline Meknes & 554 & 202210 & 271 & 98915 & 0.49 \\
\hline Mohammedia & 500 & 182500 & 180 & 65700 & 0.36 \\
\hline
\end{tabular}

Leachate treatment techniques are manifold ${ }^{15,21,22}$, including:

- Physico-chemical method: oxidation by ozone or hydrogen peroxide, coagulation, concentration, precipitation, evaporation, forced evaporation and evaporation-incineration;

- Membrane separation method reverse osmosis, nano-filtration and ultra-filtration;

- Biological method: aerated lagoons, fixed culture and membrane bioreactor;
In Morocco, at present, several experimental leachate treatment studies have been carried out but the results have not been satisfactory, we quote below some examples:

Oum Azza landfill (Municipality of Rabat) of 100 hectares managed by the PIZZORNO company produces $480 \mathrm{~m}^{3} / \mathrm{d}$ of leachate from $1792 \mathrm{t} / \mathrm{d}$ of HAW ${ }^{19}$. These leachates are treated according to the reverse osmosis process, with a cost of treatment of $214 \mathrm{DH} / \mathrm{m}^{3}$ of leachate. However, the treatment 
concerns only $10 \%$ of the total volume of leachate in addition to the concentrate resulting from this treatment still poses problems.

Landfill of Fez city of 110 hectares managed by the ECOMED company produces $360 \mathrm{~m}^{3} / \mathrm{d}$ of leachates from $900 \mathrm{t} / \mathrm{d}$ of HAW or $328.500 \mathrm{t} /$ year of HAW ${ }^{2,7}$. The solution consists of forcing the evaporation of the leachates by exploiting the heat produced from the biogas, and the residual sludge is returned to the landfill.

Besides, the start-up of this evaporator has revealed other disadvantages:

- Foaming

- Toxic gas emanation

- High energy consumption

The landfill of Agadir city covers an area of 41 hectares, managed by TECMED company for a dozen municipalities with a production of $360 \mathrm{t} / \mathrm{d}$ of HAW and $150 \mathrm{~m}^{3} / \mathrm{d}$ of leachate. The natural evaporation envisaged to eliminate this effluent by a system of recirculation and sprinkling did not lead to satisfactory results. Indeed, during the last six years of exploitation, a quantity of only $155.380 \mathrm{~m}^{3}$ was eliminated by this process, the equivalent of barely three years of leachate production.

In the light of all that has been achieved at national and international level ${ }^{23}$ and given the current state, our contribution, in the framework of this project, is to propose other alternatives to manage these leachates generated within the controlled landfills in Morocco.

This project consists first in a selective sorting of the HAW and a collection of the young leachate, then after the composting of the fermentable fraction (FF) by using the leachate collected during the first stage as process water of composting.

By taking into account the context and the stakes, this article covers all the technical and technical-economic aspects according to an integrated R\&D approach to the $3 \mathrm{R}$ concept (reduce, recycle and reuse).

This research and development work was realized in the laboratory of the National School of Mines of

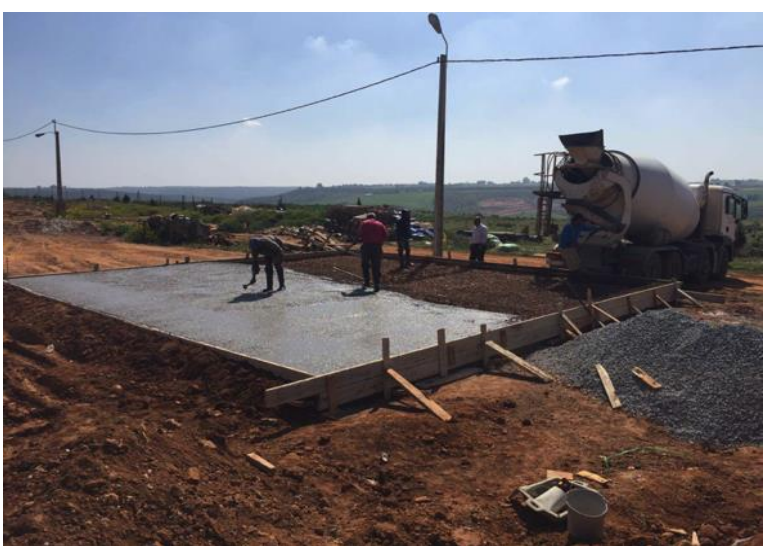

Figure 1. Photografy of platform under construction
Rabat (ENSMR) in collaboration with the State Secretariat for Sustainable Development and the laboratories mentioned above. The running parallel pilot tests in the controlled landfills of Mohammedia and Oum Azza, were done to propose a reliable and feasible solution for the treatment and valorization of leachates in Morocco.

\section{Material and Methods}

An active public dump located about $7 \mathrm{~km}$ from the center of ben yekhlef, Morocco had been selected for investigation. The area of the landfill covers 47 ha and concerns the following municipalities: Mohammedia, Beni Yakhlef, Echellalate, Benslimane, Bouznika and Mansouria, with a population of 409,000 inhabitants. 500 tons of solid wastes are being disposed daily at this site and the leachate generated are stored in evaporation ponds, the volume produced each day is estimated at $180 \mathrm{~m}^{3}$ per day.

In this study, raw leachate samples of $200 \mathrm{~L}$ were collected from the artificial pond in $25 \mathrm{~L}$ polyethylene bottles, transported to the laboratory and stored at refrigerator before being analyzed and used as process water of composting.

The study of the composting process of the fermentable fraction (FF) was carried out initially for a quantity of $770 \mathrm{~kg}$ of HAW on the site of the ENSMR and in a second time for a larger quantity of 30 tons of HAW on site of the landfill.

In order to separate by class the waste and determine the weight of each category: fermentable material, paper, plastic, textile, glass, metals, we manually carried out sorting three samples of $100 \mathrm{Kg}$.

\subsection{Preparation of composts}

Aerobic composting on a sealed surface was retained. This technique is simple and adapted to the amount of material to be treated. A platform of $100 \mathrm{~m}^{2}(10 \mathrm{~m} \times$ $10 \mathrm{~m}$ ) is built of concrete to avoid losses of soluble elements leaching during watering (Figure 1). It is sloped to allow the flow of excess water (leachate) to an evacuation view (Figure 2).

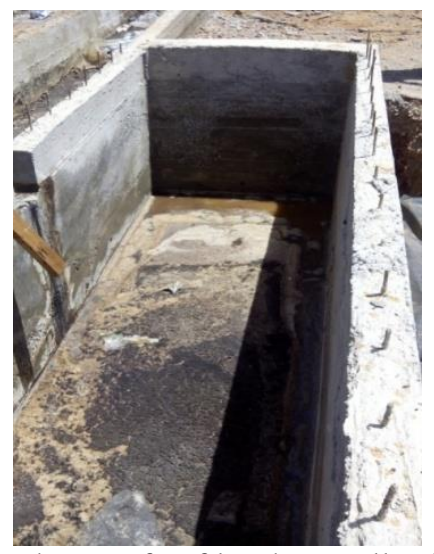

Figure 2. Photografy of leachate collection basin 
Samples were manually sorted and the fermentable fraction is packed into piles for composting. During composting, the pile was aerated to provide oxygen and mix the substrate to avoid the anaerobiosis source and create a biotope favorable to the development of the composting process.

Monitoring of the process consisted of regular measurement of the pile temperature (every 2 days), the humidity (at each reversal), the $\mathrm{pH}$ (every week) and the $\mathrm{C} / \mathrm{N}$ ratio (every 2 weeks), pile temperatures were measured with the aid of an electronic thermometer equipped with an $80 \mathrm{~cm}$ penetration probe. The evolution of the moisture during composting was followed by sampling during the return of samples which are weighed and then dried at $105^{\circ} \mathrm{C}$ up to constant weight. The $\mathrm{pH}$ of the samples is determined on an aqueous suspension at a ration $\mathrm{S}$ / $\mathrm{L}$ of $1 / 5^{24}$. An analysis of the evolution of physicochemical parameters, coupled with the sensory approach, in particular odour and colour, enabled the maturity of the composts to be estimated.

\subsection{Evaluation of some agronomic characteristics of composts.}

The laboratory compost sample $(0.5 \mathrm{~kg})$ is a mixture of six (quartering) samples taken at mid-depth and at different locations in a pile in order to obtain as representative a sample as possible. The moisture content is determined after drying at $60{ }^{\circ} \mathrm{C}$ in an oven to constant weight (to avoid deterioration of organic compounds and loss of evaporation of mineral elements). The water retention capacity (CRE) is determined by dropwise elution for $48 \mathrm{~h}^{25}$. Part of the dried samples was manually crushed and sieved to 2 $\mathrm{mm}$ for chemical analysis.
The electrical conductivity (EC) and the $\mathrm{pH}$ are determined on a $1 / 5$ aqueous extract of the milled dry matter, after 15 minutes of magnetic stirring. Total organic matter (loss on fire $550^{\circ} \mathrm{C}$ for 4 hours), total organic carbon, total nitrogen Kjeldahl, total phosphorus (perchloric acid attack), assimilable phosphorus have been performed per national and international standards. The total concentrations of $\mathrm{K}$, $\mathrm{Ca}, \mathrm{Mg}$, and metallic trace elements $(\mathrm{Cu}, \mathrm{Zn}, \mathrm{Cd}, \mathrm{Ni}$, $\mathrm{Pb})$ were determined by atomic absorption spectrometry, after mineralization of a compost sample with a mixture of $\mathrm{HNO}_{3}, \mathrm{HClO}_{4}$ and $\mathrm{HF}$, and residue recovery with $\mathrm{HNO}_{3}$ and $\mathrm{HCl}$ (SAA, 2003).

\subsection{Measurement of stability and maturity of elaborate composts.}

For stability and maturity, Haug 26 provided a subjective, yet practical definition: "the point at which the rate of oxygen consumption is reduced so that anaerobic or odorous conditions are not produced to the extent that they cause problems with storage and end-use of the product."

The stability of the compost is determined by measuring the variation of the temperature of a humidified compost sample placed in a thermos as a function of time.

The stability of the compost is determined by measuring the variation of the temperature of a humidified compost sample placed in a thermos as a function of time.

\section{Results and Discussion}

\subsection{Characterization of leachate}

The results of the physical and chemical analyzes of leachate are presented in Table 3.

Table 3. Characterization of leachate from Mohammedia landfill.

\begin{tabular}{|c|c|c|}
\hline Parameter & $\begin{array}{l}\text { Mohammedia } \\
\text { May } 2016\end{array}$ & $\begin{array}{c}\text { GRLV* } \\
\mathrm{N}^{\circ} 6199 \mathrm{du} 28 / 10 / 2013\end{array}$ \\
\hline $\mathbf{T}\left({ }^{\circ} \mathbf{C}\right)$ & 24.4 & 30 \\
\hline pH & 7.14 & $5.5-9.5$ \\
\hline SM (mg/L) & 142 & 100 \\
\hline Conductivity $(\mathrm{mS} / \mathrm{cm})$ & 35 & 2.7 \\
\hline $\mathrm{COD}\left(\mathrm{mgO}_{2} / \mathrm{L}\right)$ & 56640 & 500 \\
\hline $\mathrm{BOD}_{5}\left(\mathrm{mgO}_{2} / \mathrm{L}\right)$ & 2173 & 100 \\
\hline NTK (mgN/L) & 11844 & 40 \\
\hline $\mathrm{NH}_{4}{ }^{+}(\mathrm{mgN} / \mathrm{L})$ & 4763 & -- \\
\hline Chlorides (g/L) & 6.45 & -- \\
\hline PT (mgP/L) & 37 & 15 \\
\hline
\end{tabular}

* General Release Limit Values to Surface Water or Groundwate

Leachate analyzes show waters with high concentrations of $\mathrm{COD}, \mathrm{BOD}_{5}$, Kjeldahl nitrogen (NTK), ammonium $\left(\mathrm{NH}_{4}{ }^{+}\right)$and total phosphorus (P)... which exceed the standards for direct discharges into the natural environment.

The $\mathrm{BOD}_{5}$ has a value of $2173 \mathrm{mg} / \mathrm{l}$, and the COD is $56640 \mathrm{mg} / \mathrm{l}$, the ratio $\mathrm{BOD}_{5} / \mathrm{COD}=0.038$ indicates that the leachates taken is of stabilized type and it was in the ripening phase. This finding is confirmed by the
$\mathrm{pH}$ value above $7, \mathrm{pH}$ of the stabilized leachates (Table 1).

The concentrations of Kjeldahl nitrogen (NTK), ammonium $\left(\mathrm{NH}_{4}{ }^{+}\right)$and total phosphorus $(\mathrm{P})$ for the leachate sample in our study are respectively 11844 $\mathrm{mg} / \mathrm{l} ; 4763 \mathrm{mg} / \mathrm{l} ; 37 \mathrm{mg} / \mathrm{l}$. The presence of the NTK is due to the phenomenon of mineralization, which is a process of transformation of organic compounds into 
mineral compounds so a part of the organic nitrogen which has turned into mineral nitrogen.

The average electrical conductivity at $20{ }^{\circ} \mathrm{C}$ is of the order of $35 \mathrm{mS} / \mathrm{cm}$, indicating strong mineralization of leachate, which is most probably due to chloride ions $(6450 \mathrm{mg} / \mathrm{L})$.

\subsection{HAW Composition}

Knowledge of the composition of waste is essential in order to assess the potential for recovery such as composting, the recovery of metals or other recyclable materials: paper, cardboard, glass, plastics, and to size the processing facilities.

Table 4 shows the results of the composition by category of waste for the study area. It appears that the household waste produced in this landfill contains a large part of organic matter $(58.26 \%)$, followed by plastics $(12.73 \%)$, textiles $(3.26 \%)$, Carton and paper $(7.47 \%)$, Glasses $(1.34 \%)$, metals $(0.87 \%)$, rubble $(0.58 \%)$. These findings obtained confirm previous studies that show that organic matter is found in large quantities in household waste produced in most cities in Morocco 27.

It should be noted that the lower values in percentage composition of metals and glasses fractions is due to the development of recycling and reusing practices during the last decade.

The relatively high percentages of paper and plastic fractions can be explained by the source of these materials, which is mainly related to the industrial, commercial or administrative activity.

Table 4. HAW Composition of the Mohammedia landfill.

\begin{tabular}{|c|c|c|c|c|c|c|}
\hline & & & Fractions & & entage & \\
\hline & & stic & PET with cap & $1.34 \%$ & $12.73 \%$ & $38.76 \%$ \\
\hline & & & $\begin{array}{l}\text { High Density Polyethylene (HDPE) \& } \\
\text { Polypropylene (PP) }\end{array}$ & $0.81 \%$ & & \\
\hline O & & & $\begin{array}{l}\text { Low Density Polyethylene (LDPE): } \\
\text { plastic bags }\end{array}$ & $10.58 \%$ & & \\
\hline 3 & & ton & paper & & & \\
\hline$\tilde{\mathscr{\omega}}$ & & ious & els & & & \\
\hline$\stackrel{\sigma}{\sigma}$ & & by di & & & & \\
\hline 7 & & $\mathrm{raPa}$ & Carton & & & \\
\hline & & tiles & & & & \\
\hline & & & & & & \\
\hline & & es a & elastomer & & & \\
\hline Fermentable & orga & iic $\mathrm{m}$ & erial & & & $58.26 \%$ \\
\hline & 3 & $\begin{array}{l}\text { Iror } \\
\text { Alu }\end{array}$ & inum & & & $0.87 \%$ \\
\hline & 胕 & Alu & inum & & & \\
\hline & $\sqrt{2}$ & Alu & inum powder & & & \\
\hline & & Gla & & & & $1.34 \%$ \\
\hline & 党 & $\mathrm{Wa}$ & demolition & & & $0.58 \%$ \\
\hline & $\tilde{\mathscr{s}}$ & WE & & & & $0.10 \%$ \\
\hline & $\sum_{>}^{i}$ & $\mathrm{Me}$ & cal \& Pharmaceutical Waste (MPW) & & & $0.06 \%$ \\
\hline & $\overrightarrow{2}$ & Bat & & & & $0.02 \%$ \\
\hline Total \% & & & & & & \\
\hline
\end{tabular}




\subsection{Compost preparation and characterization}

\subsubsection{Laboratory test}

A sample of $770 \mathrm{~kg}$ of HAW from the Mohammedia landfill is manually sorted. The fermentable fraction $(462 \mathrm{~kg})$ is packed into piles for composting — the daily record of temperatures allowed to delimit the volume of the piles and the periods of reversal.

The reversal frequencies, temperatures and volumes of leachate used in the laboratory test are given in Table 5 .

Table 5. Evolution of the parameters studied in the composting operation during the period March, April, May and June (laboratory test).

\begin{tabular}{|c|c|c|}
\hline Turnaround & Pile temperature $\left({ }^{\circ} \mathrm{C}\right)$ & $\begin{array}{c}\text { Consumed volume of } \\
\text { leachate }(\mathrm{L})\end{array}$ \\
\hline 1st day & 35 & 0 \\
\hline 3rd day & 38 & 0 \\
\hline 14th day & 42 & 30 \\
\hline 21th day & 43 & 30 \\
\hline 28th day & 43 & 55 \\
\hline 35th day & 50 & 55 \\
\hline 42th day & 53 & 40 \\
\hline 44th day & 58 & 0 \\
\hline 60th day & 58 & 40 \\
\hline 64th day & 66 & 0 \\
\hline 70th day & 58 & 0 \\
\hline 77th day & 54 & 0 \\
\hline 120th day & 30 & 0 \\
\hline
\end{tabular}

The records indicate that the temperature increased slightly to around $38{ }^{\circ} \mathrm{C}$ on the 3 rd day and around $58^{\circ} \mathrm{C}$ on the 44th day (Figure 3) From there, it remained almost constant until the 60th day signaling a slowdown or even a stop of the process of degradation of the biomass. At this date, the head had the 4th turnaround to revive the microbial activity. From the 60th day to the 64th the temperature increased by eight units from $58^{\circ} \mathrm{C}$ to $66^{\circ} \mathrm{C}$. This increase corresponds to the recovery of the activity of decomposing microorganisms. It began to decrease to $30^{\circ} \mathrm{C}$ on the 120 th day.
The increase in temperature during composting is a good indicator of the evolution of biological reactions. During composting, the microorganisms degrade the biodegradable organic materials and the energy contained in the chemical bonds of the compounds is released, thus causing an increase in the temperature of the heap ${ }^{28}$.

Measurements of the temperatures recorded during the composting process indicate that the composting of the heap (FF) takes place in four phases: mesophilic, thermophilic, decreasing and stabilization whose maximum temperature reaches $66^{\circ} \mathrm{C}$, which is similar to that described by Rashad and all. ${ }^{29}$.

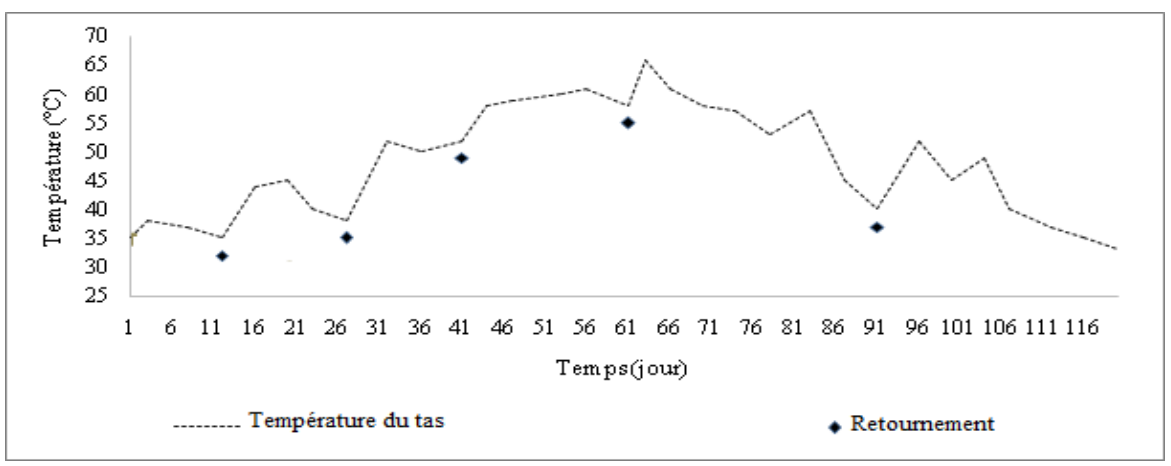

Figure 3. Evolution of the temperature during the composting of FF

The test showed that the watering of the fermentable fraction, by leachate during March, April, May and June with 10 turnarounds, consumed about 250 liters of leachate and gave a quantity of compost of $325 \mathrm{~kg}$. This test allowed us to better understand the composting parameters, but above all it showed that 
the composting operation of the fermentable fraction of the HAW of the Mohammedia landfill required the use of the equivalent of 325 liters of leachate/tonne of HAW, corresponding to an absorption of almost $90 \%$ of the leachate produced at this landfill.
The results of the physicochemical characterization of the obtained compost are presented in Table 6 , characterized by $30 \%$ humidity, a $\mathrm{C} / \mathrm{N}$ ratio of 24.9, dark brown, friable appearance, the odour of the earth with a positive germination test ${ }^{30}$. Table 6 summarizes the physicochemical analysis of the compost obtained.

Table 6. The physicochemical analysis of obtained compost.

\begin{tabular}{|c|c|c|}
\hline \multicolumn{2}{|l|}{ Parameter } & Value \\
\hline \multicolumn{2}{|l|}{ Moisture (\%) } & 30 \\
\hline \multicolumn{2}{|l|}{$\mathbf{p H}$} & 7.2 \\
\hline \multicolumn{2}{|l|}{ MO (\%) } & 69.7 \\
\hline \multicolumn{2}{|l|}{ Mineral matter (\%) } & 30.3 \\
\hline \multicolumn{2}{|l|}{ Organic carbon $(\%)$} & 34.86 \\
\hline \multicolumn{2}{|l|}{ Nitrogen (\%) } & 1.4 \\
\hline \multicolumn{2}{|l|}{ Chlorides (\%) } & 2 \\
\hline \multicolumn{2}{|l|}{ Phosphate (\%) } & 0.08 \\
\hline \multirow[t]{6}{*}{ Heavy metals (ppm) } & $\mathrm{Pb}$ & 26 \\
\hline & $\mathrm{Cu}$ & 15.7 \\
\hline & $\mathrm{Cd}$ & 6.5 \\
\hline & $\mathrm{Ni}$ & 8 \\
\hline & $\mathrm{Co}$ & 6.5 \\
\hline & $\mathrm{Cr}$ & 0.6 \\
\hline
\end{tabular}

Heavy metal content is considered another vital quality parameter necessary for protecting the soil and water resource from pollution. Heavy metals concentrations in the composts were found to be considerably lower compared to the contents found in the HAW composts from USA and European countries ${ }^{31,32}$.

These experimental results are broadly in line with international standards and reveal that quality compost can be produced from household waste in Morocco after sorting HAW.

\subsubsection{Pilote test}

The sorting of 30 tons of HAW resulted in a fermentable fraction (FF) of $58.26 \%$ with a moisture content of $86 \%$. This fraction was used as a raw material for the composting process.

Table 7 shows the temperature and moisture readings before and after the addition of leachate and the leachate volumes added to the fermentable fraction.

Table 7. Evolution of composting parameters of the fermentable fraction (pilot test).

\begin{tabular}{|c|c|c|c|c|}
\hline Date & $\begin{array}{c}\text { Temperature } \\
\left({ }^{\circ} \mathbf{C}\right)\end{array}$ & $\begin{array}{c}\text { Moisture before } \\
(\%)\end{array}$ & $\begin{array}{c}\text { Leachate } \\
\text { added }\left(\mathbf{m}^{3}\right)\end{array}$ & $\begin{array}{l}\text { Moisture } \\
\text { after (\%) }\end{array}$ \\
\hline 05/11/2016 & $18^{\circ} \mathrm{C}$ & 76.38 & $\begin{array}{c}2.2 \mathrm{~m}^{3} \\
\text { (Rainwater) }\end{array}$ & $86 \%$ \\
\hline $05 / 15 / 2016$ & $55^{\circ} \mathrm{C}$ & 56 & 0 & 56 \\
\hline $05 / 20 / 2016$ & $80^{\circ} \mathrm{C}$ & 45.37 & 3.3 & 54.6 \\
\hline $06 / 06 / 2016$ & $84^{\circ} \mathrm{C}$ & 45.26 & 2.6 & 56.8 \\
\hline 09/07/2016 & $45^{\circ} \mathrm{C}$ & 39.95 & 0 & 39.95 \\
\hline $08 / 15 / 2016$ & $30^{\circ} \mathrm{C}$ & 31.56 & 0 & 31.56 \\
\hline $09 / 15 / 2016$ & $28^{\circ} \mathrm{C}$ & 9 & 0 & 9 \\
\hline Total & --- & --- & 8.1 & --- \\
\hline
\end{tabular}

Figures 4 and 5 respectively show the shape of the composting curve of the fermentable fraction in the watering conditions with the young leachate of the
Mohammedia landfill as well as the volume of the leachates and the humidity as a function of time. 


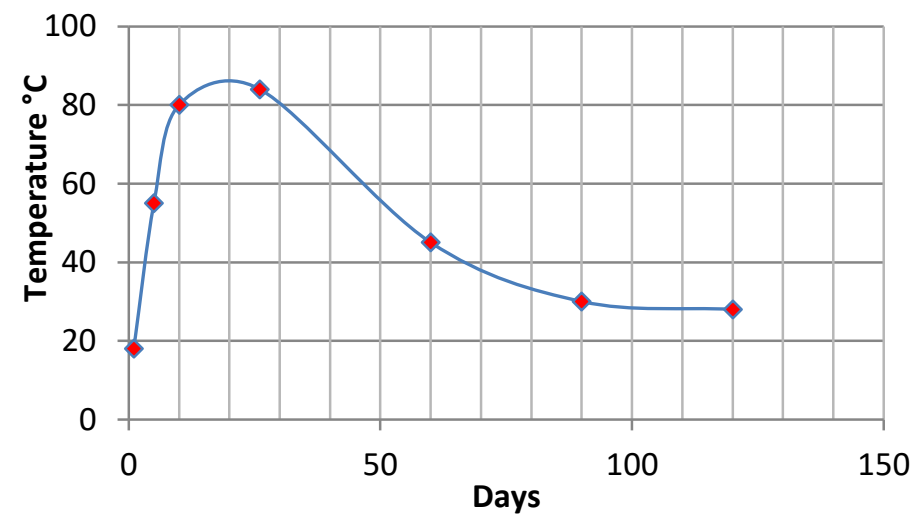

Figure 4. Composting curve of the fermentable fraction

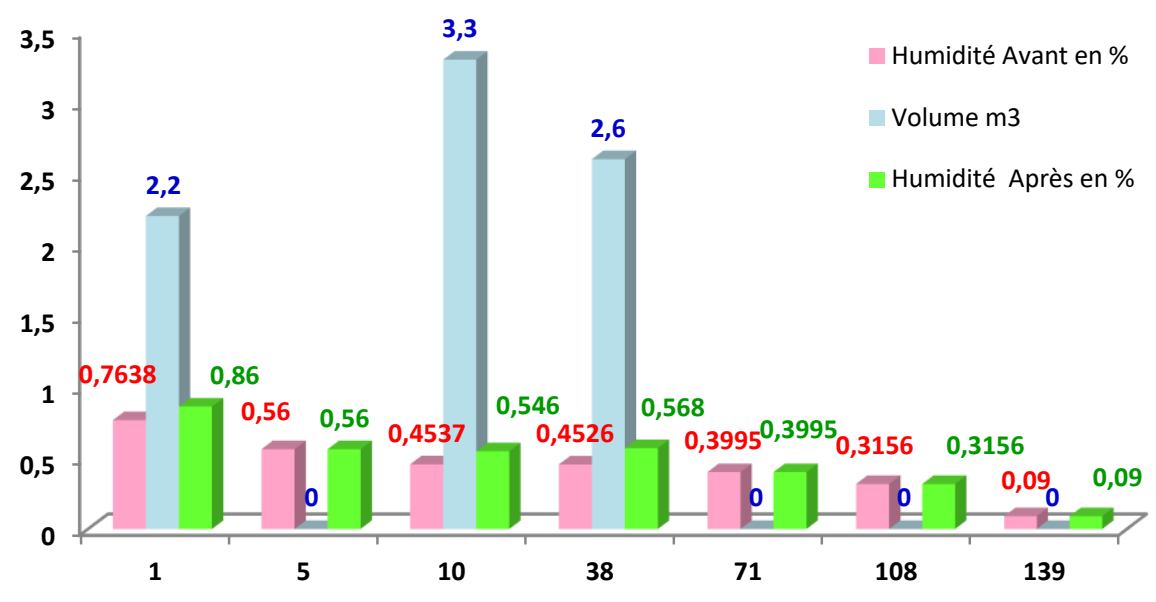

Figure 5. Added Leachate Volume and Moisture over Tim

The changes in temperature in the compost and ambient temperature over the 120 days indicated that the temperature reached its highest temperature of $86^{\circ} \mathrm{C}$ after twenty days. After three weeks, it started to decline and become stable $\left(\sim 30^{\circ} \mathrm{C}\right)$ from the 90th day (Figure 4). Figure 6 shows the heat release due to temperature rise.

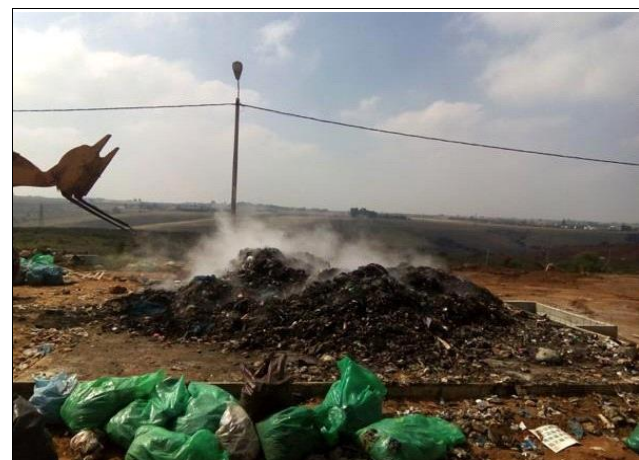

Figure 6. Reversal phase and heat release

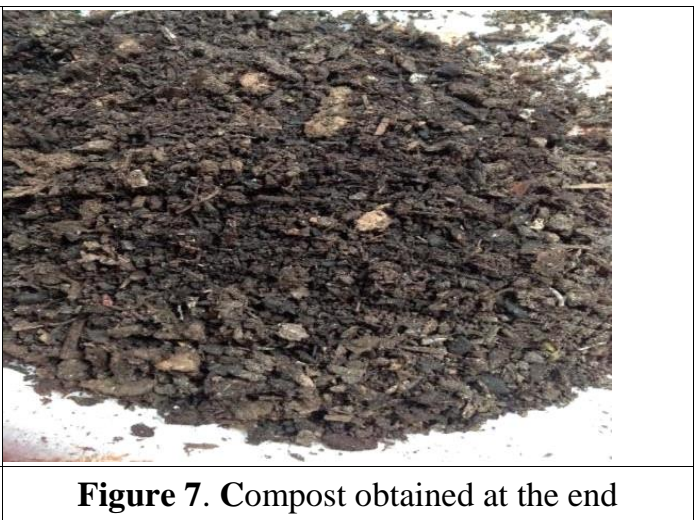

consumption of approximately $75 \%$ leachate produced by the Mohammedia landfill.

- The amount of compost obtained is 5.85 tons, with a moisture content of $9 \%$.

- $\quad$ For a moisture compost of $30 \%$, we will have 7.1 tons.

The characteristics of the compost obtained (Figure 7) are given in Table 8 . 
The stability tests of the compost as a function of the

temperature for seven days are given in Table 9.

Table 8. Characteristics of the obtained compost.

\begin{tabular}{|c|c|c|}
\hline \multicolumn{2}{|l|}{ Parameter } & Value \\
\hline \multicolumn{2}{|l|}{ Moisture (\%) } & 9 \\
\hline \multicolumn{2}{|l|}{ MO (\%) } & 54.04 \\
\hline \multicolumn{2}{|l|}{ Mineral matter (\%) } & 36.8 \\
\hline \multicolumn{2}{|l|}{ Chlorides (\%) } & 6 \\
\hline \multicolumn{2}{|l|}{ Sulfates (\%) } & 0.8 \\
\hline \multicolumn{2}{|l|}{ Phosphate (\%) } & 2 \\
\hline \multirow{8}{*}{$\begin{array}{c}\text { Metals } \\
(\mathbf{p p m})\end{array}$} & $\mathrm{Fe}$ & 4345 \\
\hline & $\mathrm{Pb}$ & 147 \\
\hline & $\mathrm{Zn}$ & 185 \\
\hline & $\mathrm{Cu}$ & 43 \\
\hline & $\mathrm{Cd}$ & $<15$ \\
\hline & $\mathrm{Ni}$ & $<15$ \\
\hline & $\mathrm{Co}$ & $<15$ \\
\hline & $\mathrm{Cr}$ & $<15$ \\
\hline
\end{tabular}

Table 9. Study of compost stability.

\begin{tabular}{|l|c|c|c|c|c|c|c|}
\hline Day & $\mathbf{1}$ & $\mathbf{2}$ & $\mathbf{3}$ & $\mathbf{4}$ & $\mathbf{5}$ & $\mathbf{6}$ & $\mathbf{7}$ \\
\hline Temperature ${ }^{\circ} \mathrm{C}$ & 18 & 25 & 25.5 & 26 & 26.5 & 27 & 28 \\
\hline
\end{tabular}

We can see that the temperature did not exceed $28^{\circ} \mathrm{C}$, which is consistent with the stability properties of composts.

\subsubsection{Description of the proposed pilot process}

The process proposed in this study aims to develop a technically and operationally efficient and economically viable tri-composting system while taking into account the main difficulties encountered in the experiments realized in Morocco.

- The trucks unload the HAW (30 t/d) on a metal grid with a mesh allowing the passage of the water $\left(6 \mathrm{~m}^{3} / \mathrm{d}\right)$ towards a basin of liquid retention and the retention of the solid fraction (24 t/d) as a heap.

- The heap is visually sorted to isolate massive size waste $(100-300 \mathrm{~mm})$.

- A conveyor conveys the waste on a sorting platform riddled with holes $8 \mathrm{~mm}$ in diameter (to separate fine extraneous waste, sands, ...) with the following dimensions: $2 \mathrm{~m}$ wide, $10 \mathrm{~m}$ long and $1 \mathrm{~m}$ of the ground. This platform makes it possible to separate manually the waste of average size (100$200 \mathrm{~mm})$ and in particular the fine waste $(8-20 \mathrm{~mm})$. This sorting step is very interesting to ensure the quality of compost free of any undesirable substance. It is realized by 20 sorters which ensure around $24 / 20=1.2 \mathrm{t} / \mathrm{d} /$ sorter (ie a sorter assuring $150 \mathrm{~kg} / \mathrm{h}$ at the rate of 8 working hours per day).

- For the solid fraction of $10 \mathrm{t} / \mathrm{d}$, recyclables (metals, glass, plastic) and those oriented towards energy recovery (AF) are recovered by positive sorting and deposited in four barrels of 20 liters each and the fermentable fraction $(\mathrm{FF})$ remains on the sorting table then conveyed by a conveyor to form a pile at the exit of the sorting factory $(14 \mathrm{t} / \mathrm{d})$.

Figure 8 presents a simplified Layout of the Sorting factory. The infrastructure and equipment needed to set up the operation of this factory are sorting platform, press, two conveyors, metal grid as well as the leachate pumping system or water. 


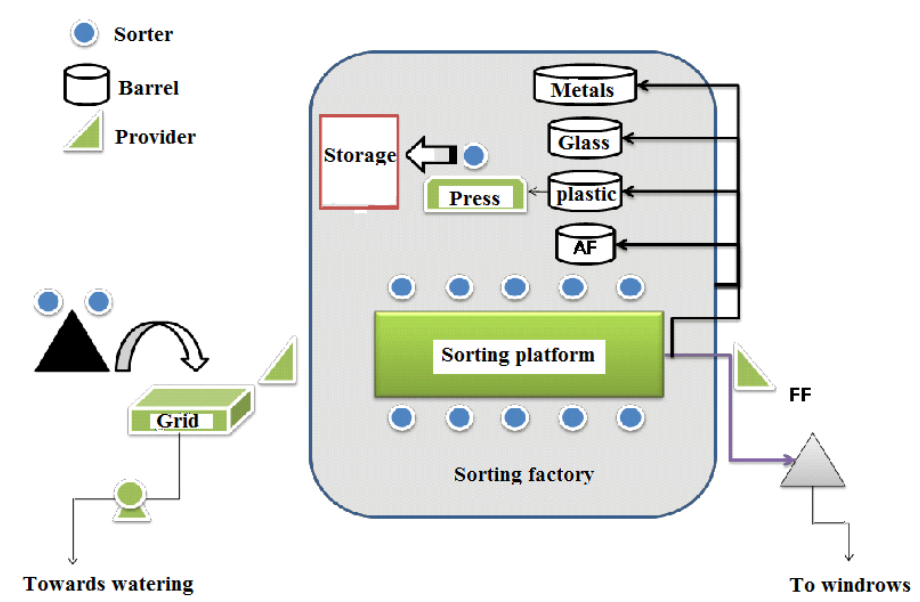

Figure 8. Sorting factory of the composting unit

At the end of the tri factory, $14 \mathrm{t} / \mathrm{d}$ of the fermentable fraction $(\mathrm{FF})$ is recovered. This material has a density of approximately $0.4 \mathrm{t} / \mathrm{m}^{3}$, for a total volume of $35 \mathrm{~m}^{3}$ per day.

\subsubsection{Windrow construction and dimensions}

- Composting through the construction of 10 windrows in rows spaced 4 meters apart (for machine traffic) (Figure 9).

- For technical reasons and given the production of $14 \mathrm{t} / \mathrm{d}$ of the fermentable fraction, after seven days we will have a windrow width $6 \mathrm{~m}$, height $2.5 \mathrm{~m}$ and a length $32.7 \mathrm{~m}$, a volume of $35 \times 7=245 \mathrm{~m}^{3}$.

- For a period of 70 days, the time of the first phase of manufacture of the compost, we will have 10 windrows occupying an area of:

$(32.7+4 \times 2) \times[(10 \times 6)+(4 \times 11)]=4232.8 \mathrm{~m}^{2}$

\subsubsection{Operating mode}

- The first window is placed at a distance of $60 \mathrm{~m}$ from the sorting platform.

- The assembly of the 1 st swath lasts 7 days.

- From the eighth day, we start to deposit the 2nd windrow, which lasts another 7 days, at the same time, we proceed to the turnaround of the 1st swath for the phase of aeration.

- On the 15th day, the first windrow and the 2nd windrow are turned over, and then the third windrow is started.

- On the 22nd day, a turnaround of the 1st, 2nd and 3rd windrow and we start the assembly of the 4th windrow.

- The 29th day, a turnaround of the 1st, 2nd, 3rd, 4th windrow and we start the assembly of the 5th windrow.

- On the 70th day, the 1st windrow is moved to storage in the hangar of an area of about $500 \mathrm{~m}^{2}$ sheltered from the weather, to undergo the maturation phase which lasts 30 days. The 2 nd windrow will take the place of the 1 st, the 3rd windrow will take the place of the 2nd and so on, which frees the place of the 10th windrow to start a new cycle of production. Each windrow will undergo 10 turnarounds during the fermentation phase (once a week).

- The production of 1 st windrow compost weighs 7.1 tons or 49.7 tons every 7 days, which gives an annual production of about $2590 \mathrm{t} /$ year.

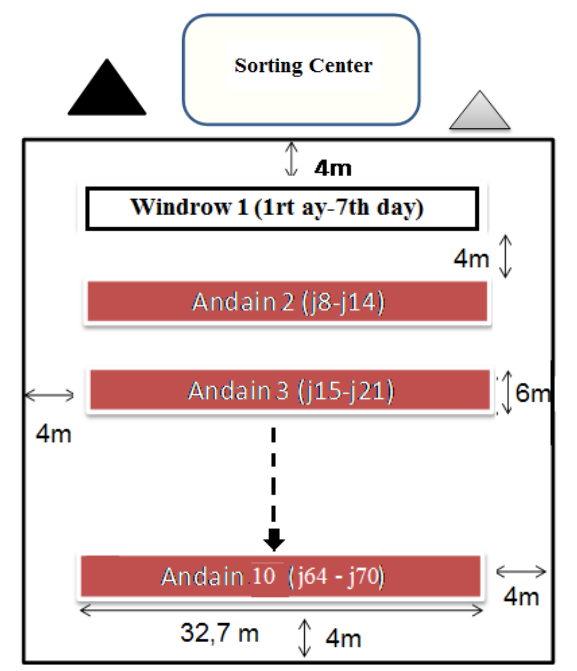

Figure 9. Arrangement of windrows in the fermentation area

It emerges from all these experiences; the following findings:

- This process consumes $300 \mathrm{~L}$ of leachate per tons of HAW. This result remains very interesting because it makes it possible to eliminate the leachates already stored.

- The compost analysis shows that the final product meets safety and use standards as a fertilizer to improve agricultural land by improving the $\mathrm{C} / \mathrm{N}$ ratio by adding nitrogen-rich materials such as Chicken dung (Making a new balanced compost from the fermentable part of household refuse and chicken dung. 
- The compost obtained has an organic material content of about $54 \%$, which also makes it possible to use it as a substitute fuel by making briquettes.

\section{Conclusion}

The study that we carried out made it possible to propose a solution for the leachate management which poses problems at the level of all the dumps in Morocco. This solution is characterized by several advantages which can be summarized as follows:

\section{Technical advantages}

- Reduced leachate and HAW volume

- Increased life of the landfill site (60\% removal of HAW);

- Recycling of plastic waste, glass, cardboard / paper and organic

- Develop biotechnology

- Improved landfill management;

- Simple and possible technical feasibility,

Socio-economic advantages

- Social integration of unskilled labor and job creation (170 workers to handle $250 \mathrm{t} / \mathrm{d}$ of HAW;

- Creation of waste recovery cooperatives in landfills;

- Wealth creation and development of the circular economy.

\section{Environmental advantages}

- Reduction of the volume of waste

- Contribution to reducing the emission of greenhouse gases,

- Reduction of pollution of water and soil resources by leachates,

- Production of compost for the natural amendment of soils and rehabilitation of soils subject to agricultural intensification;

Educational Advantages - Sensitization of Environmental Preservation:

The educational visits of treatment centers and valorization of HAW, groups of students and members of associations, allow taking into account the different types of treatment of household waste in the city.

\section{Acknowledgements}

We would like to thank the partners who supported this work: The Pizzorno, ECOMED companies and the State Secretariat (Morocco) in charge of Sustainable Development.

\section{References}

1- A. El Maguiri, B. Kissi, L. Idrissi, S. Souabi, Landfill site selection using GIS, remote sensing and multicriteria decision analysis : case of the city of Mohammedia, Morocco. Bulletin of Engineering Geology and the Environment, May 2016 (DOI 10.1007/s10064016-0889-z).
2- $\quad$ M. A. Bruner, Rao, M., J.N. Dumont, M. Hull, T. Jones, J. A. Bantle. Ground and surface water developmental toxicity at a municipal landfill: description and weather-related variation. Ecotoxicol. Environ. Saf., 1998, 39, 215-226.

3- T. Bortolotto, J. B. Bertoldo, da Silveira, F. Z., Defaveri, T. M., Silvano, J., Pich, C.T., Evaluation of the toxic and genotoxic potential of landfill leachates using bioassays. Environ. Toxicol. Pharm., 2009, 28, 288-293.

4- A. Melnyk, K. Kuklińska, L. Wolska, J. Namieśnik, Chemical pollution and toxicity of water samples from stream receiving leachate from controlled municipal solid waste (MSW) landfill. Environmental Research, 2014, 135, 253-261.

5- R. Mejbri, G. Matejka, P. Lafrance, M. Mazet, Fractionnement et caractérisation de la matière organique de lixiviats des décharges d'ordures ménagères, Revue des sciences de l'Eau,1995, 8, 217-236.

6- A. Baun, A. Ledin, L. A. Reitzel, P. L. Bjerg, T. H. Christensen, Xenobiotic organic compounds in leachates from ten Danish MSW landfills - chemical analysis and toxicity tests. Water Res., 2004, 38, 3845-3858.

7- Y. Ezzoubi, M. Merzouki, L. Bennani, A. El Ouali Lalami, M. Ben Lzmlih, Procédé pour la réduction de la charge polluante du lixiviat de la décharge contrôlée de la ville de Fès, Déchets Sciences et Technique, 2010, $N^{\circ} 58$, 2ème trimestre.

8- Y. Jirou, M. C. Harro Uni, M. Belattar, M. Fatmi, S. Daoud, Rev. Mar. Sci. Agron. Vét. 2014, 2 (2), 59-69.

9- F. Benyoucef, A. Elghamal, A. Ouatmane, Etude expérimentales du traitement par évaporation forcées des lixiviats de déchets ménagers de la ville de Kasba Tadla, Sciences \& Techniques, 2015, $\mathrm{N}^{\circ} 70$.

10- H. Lekehal, B. Benzougagh, K. Mimich, Lixiviats issus de la décharge Publique de la ville de Meknès. Calcul de bilan hydrique, European Scientific Journal, 2016, 12, N²9.

11- Dorota Kulikowska, Ewa Klimiuk, The effect of landfill age on municipal leachate composition, Bioresource Technology, 2008, 99, 5981-5985.

12- G. Andreottola, P. Cannas, Chemical and biological characteristics of landfill leachate, Elsevier Appl. Sci., 1992, 9, 65-88.

13- L. M. Chu, K.C. Cheung, M.H. Wong, Variations in the chemical properties of landfill leachate, J. Environ. Manage., 1994, 18, 105-117.

14- Le premier congrès international sur la gestion intégrée de déchets, Skhirat, Morocco, 21 Juin 2014- 07-31.

15- J. D. Enzminger, D. Robertson, R. C. Ahlert and D. S. Kosson, Treatment of landfill 
leachates. Journal of Hazardous Materials, 1987, 14, 83-101.

16- S. M. Raghab, A. M. Abd El Meguid, H. A. Hegazi, Treatment of leacha te from municipal solid waste landfill. HBRC Journal, 2013, 9, 187-192.

17- M. A. Kamaruddin, M. S. Yusoff, H. Abdul Aziz, Y. Hung, Sustainable treatment of landfill leachate. Appl Water Sci, 2015, 5, 113-126.

18- Etude de faisabilité relative à l'amélioration de la gestion de la décharge publique de Tanger (Maroc). Rapport du Ministère de l'aménagement du territoire de l'eau et de l'environnement-GTZ 2006.

19- G. Prenant, Rapport de la société PIZZORNO, Régional Workshop Casablanca, Morocco, Septembre 2015.

20- A. Fekri, J-L. Pineau, M. Wahbi, A. Benbouziane, C. Marrakchi, Les lixiviats de la décharge de déchets urbains de la ville de Casablanca (Maroc), une pollution annoncée, Déchets, Sciences et Techniques, 2006, N42.

21- R. Stegmann, K.-U. Heyer AND R. Cossu, Leachate Treatment. Proceedings Sardinia, Tenth International Waste Management and Landfill Symposium, 3-7 October 2005, Cagliari, Italy.

22- P. Yao, Perspectives on technology for landfill leachate treatment. Arabian Journal of Chemistry, 2017, 10, S2567-S2574.

23- P. Sarmah, T. Tanu Dutta, S. Sen \& R. Sarmah, Design, of a Combination of Compost Plant and Landfill for Municipal Solid Waste Management of Guahati City, International Journal of Civil, Structural, Environmental and Infrastructure Engineering Research and Development, Aug 2015, Vol. 5, Issue 4, 45-52.

24- O. N. Belyaeva, R. Haynes, Chemical, microbial and physical properties of manufactured soils produced by co-composting municipal green waste with coal fly ash. Bioresource Technology, 2009, 100, pp: 5203-5209.

25- M. Pansu \& J. Gautheyrou, L'analyse du sol minéralogique, organique et minérale, Springer-Verlag, , 2003, 995 p.

26- R. T. Haug, The practical handbook of compost engineering. Boca Raton, 1993, Florida, 717 p.

27- Programme CoMun, Morocco, Coopération Allemande GIZ, www.co-mun.net.

28- Optimization for Temperature and Time in Composting Municipal Solid Waste and Brewery Sludge, International Journal of Environmental Engineering and Management, 2016, Volume 7, $\mathrm{N}^{\circ} 1$, pp. 1-23.

29- F. M. Rashad, W.D. Saleh, M.A. Moselhy, Bioconversion of Rice Straw and Certain AgroIndustrial Wastes to Amendments for Organic Farming Systems Composting, Quality, Stability and Ma-turity Indices, Bioresource Technology, 2010, 101, 5952-5960.

30- A. Ihihi, M. Kitane, I. Lakhtib, A. Bahloul, C. Benqlilou, K. El Kacemi, Fabrication d'un nouveau compost équilibré à partir de la partie fermentescible des ordures ménagères et de la fiente de poulet, Scientical Editions Mersenne, 2014, 1, $\mathrm{N}^{\circ}$ 1312, ISSN : 2272-864.

31- X. He, S.J. Traina, T.J. Logan, Chemical properties of municipal solid waste composts, Journal of Environmental Quality, 1992, 21, 318-329.

32- L. Herity, A study of the quality of waste derived compost in Ireland. Thesis submitted in partial fulfillment of the requirements for the degree of Master of Science in Environmental Engineering. Faculty of Engineering, Queens University of Belfast, Ireland. (accessed on 27.02.09.), 2003.

33- M. S. Finstein and M. L. Morris, Microbiology of municipal solid waste composting, Advances in Applied Microbiology, 1986, 19, 113-151. 